\title{
Early Pleistocene volcanism in the Emile Baudot Seamount, Balearic Promontory (western Mediterranean Sea)
}

\author{
J. Acosta ${ }^{\mathrm{a}, *}$, E. Ancochea ${ }^{\mathrm{b}}$, M. Canals ${ }^{\mathrm{c}}$, M.J. Huertas ${ }^{\mathrm{b}}$, E. Uchupi ${ }^{\mathrm{d}}$ \\ a Instituto Español de Oceanografía, Corazón de María no. 8, 28002 Madrid, Spain \\ ${ }^{\mathrm{b}}$ Dpto. Petrología y Geoquímica, Facultad de Ciencias Geológicas, Universidad Complutense de Madrid, 28040 Madrid, Spain \\ ' GRC Geociències Marines, Departament d’Estratigrafia, Paleontología i Geociències Marines, Facultat de Geología, \\ Universitat de Barcelona, Campus de Pedralbes, E-08028 Barcelona, Spain \\ ${ }^{\mathrm{d}}$ Woods Hole Oceanographic Institution, Woods Hole, MA 02543, USA
}

Received 14 November 2002; received in revised form 2 March 2004; accepted 7 April 2004

\begin{abstract}
The recovery of calcareous breccia and other carbonate-cemented rocks from Mont dels Oliva in the Balearic Promontory indicates that both this seamount and the adjacent Mont Ausias Marc, east of Ibiza and Formentera islands, are of continental origin. Recent multibeam echosounder mapping and high-resolution seismic reflection profiles indicate that the third high, Emile Baudot Seamount, is located within a field of more than 118 pinnacles. Based on their magnetic signature and the recovery of basalt in the vicinity of the pinnacles suggest that the features are of volcanic origin. A basalt sample dredged from Emile Baudot Seamount indicates an igneous origin for this seamount. The limited sampling, the chemistry of the rock recovered and the size of the seamount itself $(18$ by $3 \mathrm{~km}$ ), however, does not preclude the possibility that Emile Baudot may be a fractured uplifted continental block intruded by the basalt. The K/Ar age of $1.46 \pm 0.18$ my yielded by the basalt sample verifies the earlier proposal by Acosta et al. (Mar. Pet. Geol. 128 (2001a) 349) that the volcanism that created part or all of Emile Baudot Seamount and the Southwest Majorca Volcanic Field associated with the seamount took place in the Pleistocene. This volcanism is probably related to decompression resulting from the normal faulting that led to the subsidence of the low (Central Depression) between Ibiza and Majorca (Balearic Islands).
\end{abstract}

Keywords: Pleistocene volcanism; Emile Baudot Seamount; South Majorca Volcanic Field; Balearic Promontory

\section{Introduction}

Prior to 1990, the morphology and structure of Mont dels Oliva and Mont Ausias Marc seamounts east of Ibiza (Eivissa) and Formentera and Emile Baudot Seamount along the crest of the Emile Baudot

* Corresponding author. Tel.: +34-91-347-3618; fax: +34-91413-5597.

E-mail address: juan.acosta@md.ieo.es (J. Acosta).
Escarpment in the Balearic Promontory were investigated during various cruises by the Instituto Español de Oceanografia (Palomo et al., 1974, Acosta et al., 1986, 1989) (Fig. 1).

The purpose of these investigations were to determine their origins, volcanic or uplifted sedimentary blocks, information critical to our understanding of the evolution of the Balearic Promontory. As no wells have been drilled on the promontory and the DSDP and ODP sites (see Acosta et al., 2001a and 


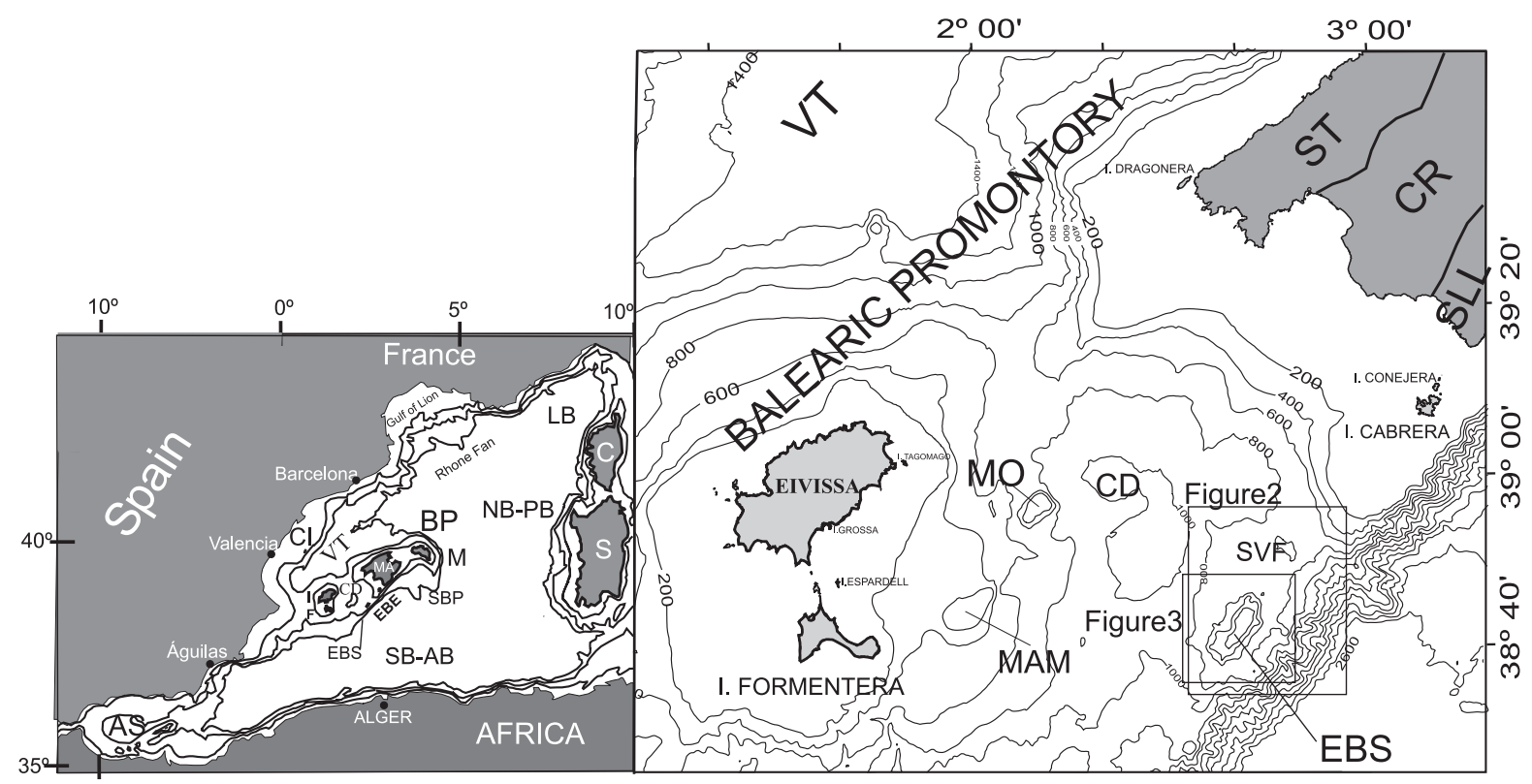

Fig. 1. Bathymetry of the western end of the Balearic Promontory showing locations of islands along its crest, central depression (CD), Emile Baudot Seamount (EBS), Mont dels Oliva (MO), Mont Ausias Marc (MAM) and the Southwest Volcanic Field (SVF). ST = Serra Tramuntana, $\mathrm{SLL}=$ Serra Llevant, $\mathrm{CR}=$ Central Rift. Compiled from Acosta et al. (2001a) and Grupo de Trabajo ZEE (2001). Inset is morphology of the Balearic Promontory region in the western Mediterranean. Modified from GEBCO Sheet 5.05. Contours of both maps are in meters. $\mathrm{AS}=$ Alboran Sea; $\mathrm{BP}=$ Balearic Promontory; $\mathrm{C}=$ Corsica; $\mathrm{CI}=$ Columbretes Islands; $\mathrm{CD}=$ Central Depresion; $\mathrm{EBE}=\mathrm{Emile} \mathrm{Baudot}$ Escarpment; EBS = Emile Baudot Seamount; F=Formentera; I=Ibiza; LB=Ligurian Basin; M= Menorca; MA=Mallorca; NB $-\mathrm{PB}=\mathrm{North}$ Balearic-Provençal Basin; $\mathrm{S}=$ Sardinia; $\mathrm{SB}-\mathrm{AB}=$ South Balearic - Algerian Basin; $\mathrm{SBP}=$ South Balearic Plateau; VT=Valencia Trough.

references therein) are off the promontory in the adjacent deep basins any data regarding the nature of the stratigraphy of the region is of urgent need for those working in the western Mediterranean. No matter how meager the data may be, these data should be circulated as widely as possible.

\subsection{Methods}

Morphologic and structural studies during the cruises were made with the aid of $3.5-$ and $12-\mathrm{kHz}$ echosounders, a single-channel high-resolution seismic reflection profiler and a proton precession magnetometer (Palomo et al., 1974, 1976). The seismic profiler used was a sparker with a capacity of 800 to $1000 \mathrm{~J}$ fired at 1 -s intervals with the signals being detected with an 8-element EG \& G hydrophone and recorded on an EPC recorder using a 0.25 - and 1.0-s sweep. In December 2000 data collected on the highs during these cruises were used to select areas to survey with a ROV video system and to sample with a rock dredge. This work was carried aboard the $\mathrm{R} / \mathrm{V}$ Odón de Buen of the Instituto Español de Oceanografía. Navigation during the cruise was by means two GPS systems receiving differential corrections from Omnistar.

More recently, the highs were included in a general survey of the region with the aid of a Simrad multibeam EM-12S and EM-1000 echosounding systems aboard the R/V Hesperides. Multibeam data acquired insonified $100 \%$ of the seafloor with at least $33 \%$ overlap of the echosounding corridors. These data were used to generate topographic maps and digital terrain models of the area (Muñoz et al., 1997) that met the standards specified by the International Hydrographic Organization (1997) for multibeam surveys. The last investigation is part of the survey of Spanish Exclusive Economic Zone by the Instituto Español de Oceanografia and the Instituto Hidrográfico de la Marina (Acosta et al., 2001a). 


\section{Geographic and geologic setting}

The Balearic Promontory in the western Mediterranean Sea is a northeast extension of the Neogene Betic System in southern Spain. The high is about 348 $\mathrm{km}$ long, $105 \mathrm{~km}$ wide and has a relief of 1000 to $2000 \mathrm{~m}$ (Fig. 1). Northwest of the promontory is the Valencia Trough, with the Balearic-Provençal Basin located along its northeast side, and the BalearicAlgerian Basin on its southeast side. Forming the southeast side of the promontory is the 800- to 1500-m-high Emile Baudot Escarpment with a declivity of $6.5^{\circ}$ to $7.9^{\circ}$ (Acosta et al., 2001a).

Southeast of Emile Baudot Escarpment is the Algerian basin, with a recent, very thin and weakly reflective crust of probably oceanic character (Sabat et al., 1995).

The promontory is divided into three blocks by three northwest-oriented lows. One at its southwest end at $0^{\circ} 50^{\prime} \mathrm{E}$ separates the high from the Spanish margin, another, an elliptical depression (Central Depression; Fig. 1) located about $70 \mathrm{~km}$ northeast from the previous low, is at $2^{\circ} \mathrm{E}$ and a poorly defined low is located near $3^{\circ} 30^{\prime} \mathrm{E}$. Along the crest of the promontory are the Balearic Islands (Fig. 1). Other positive topographic elements along the crest of the Balearic Promontory are three seamounts. Mont dels Oliva and Mont Ausias Marc seamounts east of Eivissa (Ibiza) and Formentera along the west side of the central low and Emile Baudot Seamount is along the crest of Emile Baudot Escarpment at the southeast mouth of the Central Depression.

The Serres de Llevant and Serra de Tramuntana zones along the Southeast and Northwest sides of Majorca island, respectively, are made of Cenozoic and older rocks that were folded prior to the Miocene and thrust faulted northwestward up to the middle Miocene. These compressional phases were followed by a rift phase in late Miocene that formed the Central Rift separating the Serres de Llevant and Serra de Tramuntana (Fig. 1).

\section{Seamounts}

Mont dels Oliva located east of Eivissa (Ibiza) is $8 \times 6 \mathrm{~km}$, has a relief of about $300 \mathrm{~m}$ with its base at a depth of $600 \mathrm{~m}$ and its top at $300 \mathrm{~m}$ (Fig. 1). The seamount is elliptical in plan view with its long axis trending northeast. Mont Ausias Marc, northeast of Formentera, is $14 \times 10 \mathrm{~km}$, has a relief of $200 \mathrm{~m}$ with its base at a depth of $300 \mathrm{~m}$ and its top at $<125 \mathrm{~m}$. This high also is elliptical in plan view with its long axis also oriented northeast. Studies by Palomo et al. (1974) and Acosta et al. (2001b) indicate that Mont dels Oliva and Mont Ausias Marc, respectively, named as Monte Norte and Monte Sur, have cores of highly reflective material, that their crests are flat indicating that they have undergone marine planation and that Mont Ausias Marc is cut by a fault oriented NE-SW having surface expression. Recovery of carbonate rocks from Mont dels Oliva suggests that the seamounts represent uplifted exposures of Cenozoic and possibly older rocks that form the core of the Balearic Promontory.

Emile Baudot Seamount located along the crest of the Emile Baudot Escarpment is $18 \mathrm{~km}$ long and $3 \mathrm{~km}$ wide (Figs. 1 and 2). In plan view, the high is a rectangular block asymmetrical in cross-section with a gradient of $16.7^{\circ}$ on its southeast side and $16.2^{\circ}$ on the northwest side (Acosta et al., 2001a). The seamount has a relief of $>500 \mathrm{~m}$ with its base at a depth of $650 \mathrm{~m}$ and is flat-topped at a depth of less than 100 $\mathrm{m}$. It is elongated in a northeast direction along the trend of the Emile Baudot Escarpment. The seamount is located on the crest of a northeast trending mound at the end of a southwest trending swell. This swell is aligned along the northeast trend of the Serres de Llevant on the southeast side of Majorca. Along the crest of this swell are three highs. The easternmost one has a relief of $100 \mathrm{~m}$, and trends northeast, and has a minimum depth of $<350 \mathrm{~m}$. The central high trends east-west, has a relief of about $150 \mathrm{~m}$ and a minimum depth of $<650 \mathrm{~m}$. The high along which Emile Baudot Seamount is located trends northeast with a minimum depth of $<100 \mathrm{~m}$ and relief of $700 \mathrm{~m}$.

A seismic reflection profile of Emile Baudot Seamount shows that on the crest of the seamount are two terraces at depths of 150 and $161 \mathrm{~m}$. Covering these terraces is an irregular surfaced acoustic transparent unit that may represent a carbonate cap. The steeper eastern slope of the seamount consists of a perched sediment wedge resting on a strong reflecting horizon that may define a buried terrace at a depth of $0.5 \mathrm{~s}$ (375 m) (Acosta et al., 2001a, their Figs. 13 and 14). At the base of the seamount is an irregular surface 


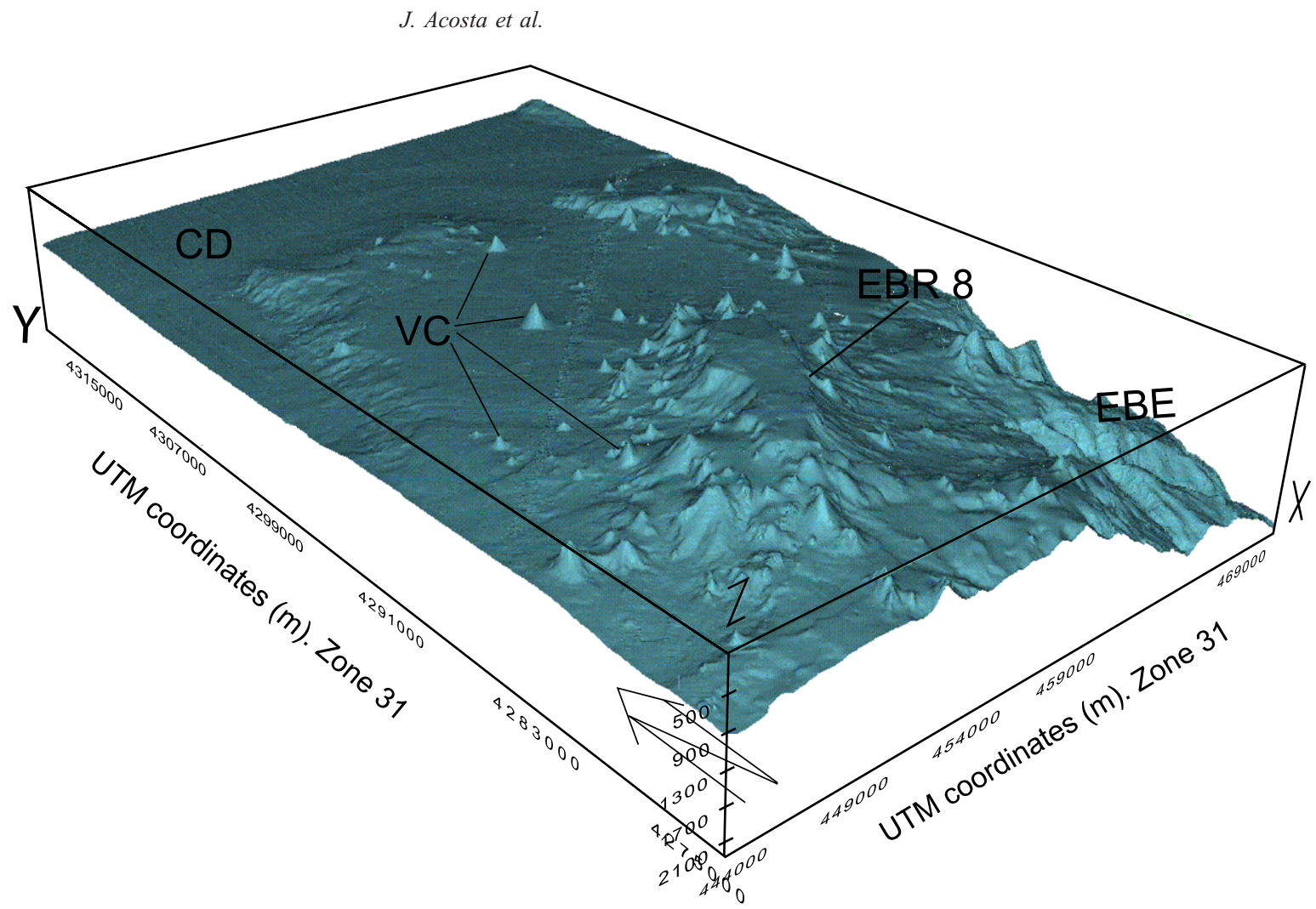

Fig. 2. 3D diagram based in multibeam echosounder data, showing the Emile Baudot Seamount morphology. Arrow: rock sample location. Small highs (VC) surrounding the seamount are the volcanic pinnacles of the Southwest Majorca Volcanic Field. CD $=$ Central Depresion. $\mathrm{EBE}=$ Emile Baudot Escarpment. See Fig. 1 for location.

sediment deposit that we infer to be a slump. On the seamount's gentler west side, there is a convex upward sediment deposit that appears to have been deposited in a low between two pinnacles. Farther downslope is a sediment apron that accumulated behind a pinnacle. West of this pinnacle is a westerly dipping strong reflecting horizon (VC). Acosta et al. (2001a) mapped this horizon throughout much of the topographic low between Eivissa (Ibiza) and Majorca and from its association with the volcanic peaks (see below) infer that it represents either the top of a lava flow or volcaniclastics. The reflector at the western end of the profile (M) was correlated by Acosta et al. (2001a) with the upper Miocene Pan-Mediterranean reflector (top of the Messinian evaporites). Above horizons $\mathrm{VC}$ and $\mathrm{M}$ is a transparent unit above which is a well stratified sequence. Alla et al. (1972) has inferred that the transparent unit is of Pliocene age and the upper stratified sequence of Quaternary age. Alla et al. (1972), Alonso et al. (1991) and Escutia and Maldonado (1992) have suggested that the two units are separated by an unconformity, Reflector G.

Seismic reflection profiles and multibeam echosounding data shows that at least 118 pinnacle structures occur on the swell along which the Emile Baudot Seamount is located. They have vertical reliefs of 50 to over $200 \mathrm{~m}$, basal widths of 200 to $2100 \mathrm{~m}$, and side slopes with gradients ranging from $14^{\circ}$ to $32^{\circ}$ (Acosta et al., 2001a, 2002). One of these structures near $38^{\circ} 30^{\prime} \mathrm{N}$, isolated from the rest of the pinnacles, is flat-topped. The pinnacles display two trends, northeast parallel to the long axis of Emile Baudot Seamount and northwest. Acosta et al. (2001a) noted that the pinnacles defined a 12-34$\mathrm{km}$-wide and 39-km-long field elongated northeastward, a trend that is well defined in the vicinity of Emile Baudot Seamount and by the magnetic anomalies mapped by Palomo et al. (1974). Acosta et al. 
(2001a) named this field the Southwest Majorca Volcanic Field (SVF, Fig. 1).

The recovery of basalt by Desforges (1973) in the area of the pinnacles and the northeast trending magnetic anomalies in excess of $700 \mathrm{nT}$ mapped by Palomo et al. (1974) led Acosta et al. (2001a) to infer that the pinnacles are of igneous origin and that the associated Horizon $\mathrm{VC}$ is either a lava flow or volcaniclastics, although it may also represent a sill. The total magnetic field in the region of the Emile Baudot seamount is imaged in Fig. 3 with the anomalies displayed by the map being based on using a value of $+43,000 \mathrm{nT}$ as a base of reference. As imaged by Fig. 3, the magnetic field associated
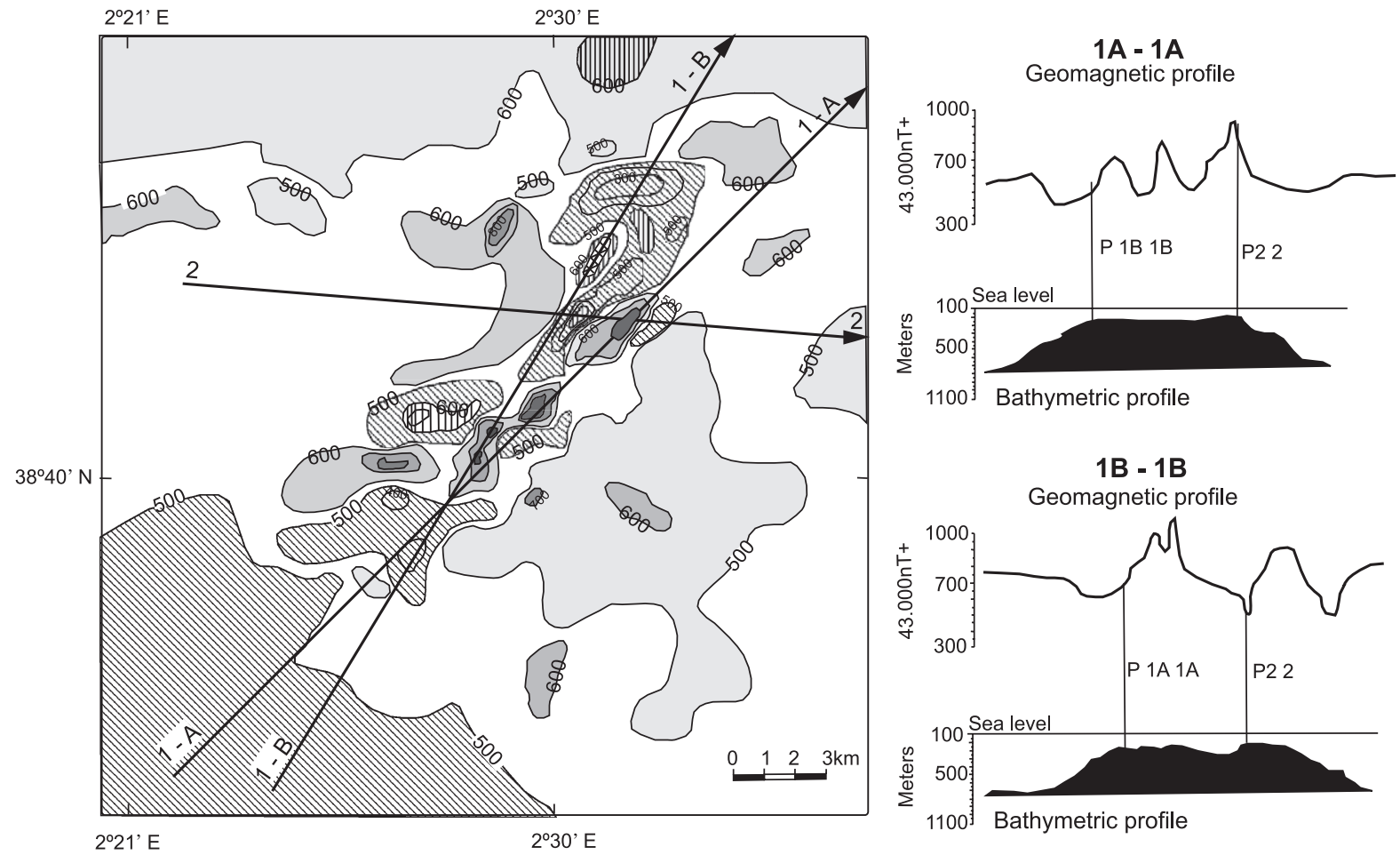

$1 B-1 B$

Geomagnetic profile

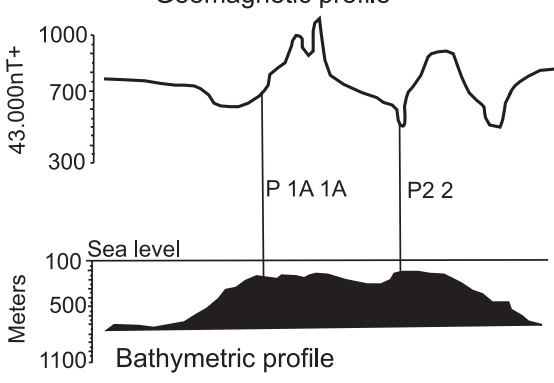

2 - 2

Geomagnetic profile

RELATIVE POSITIVE ANOMALY (nT) RELATIVE NEGATIVE ANOMALY (nT)

\begin{tabular}{|c|c|c|}
\hline 500 to 600 & MIII & 400 to 500 \\
\hline 600 to 700 & ||||| & 500 to 600 \\
\hline 700 to 800 & $\infty$ & $>600$ \\
\hline$>800$ & & \\
\hline
\end{tabular}

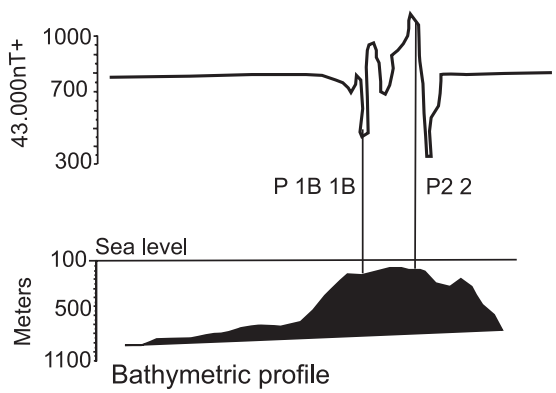

Fig. 3. Total geomagnetic force map and selected magnetic/bathymetric profiles of the Emile Baudot Seamount. Modified from Palomo et al. (1974) The map was constructed using a value of $+43,000 \mathrm{nT}$ as a level of reference. The magnetic data used to compile the map has been corrected for diurnal variations and magnetic storms using data from the Toledo Observatory with a reference epoch of 1974.5. Stippled pattern: relative positive anomalies; line pattern: relative negative anomalies. See Fig. 1 for location. 
with Emile Baudot Seamount consists not of a prominent magnetic high, but of a series of narrow highs and lows trending northeast-southwest that are bordered on the northeast by an east-west trending magnetic low. Magnetic and bathymetric profiles show that these anomalies with amplitudes of about $\pm 300 \mathrm{nT}$ are located over the crest of Emile Baudot Seamount. All in all the magnetic fabric appears to be a consequence of a series of magmatic intrusions along northeast trending structural weaknesses on the country rock rather than one massive igneous emplacement. Thus, our speculation that the Emile Baudot Seamount may represent an intruded country rock high and not a true volcanic seamount.

From its stratigraphic relation to the upper Miocene Horizon M horizon VC is of post-Miocene age. Acosta et al. (2001a) proposed that both the pinnacles and Emile Baudot Seamount were probably emplaced along northeast aligned fractures. They noted that such an origin for the seamount is compatible with the structural model proposed by Auzende et al. (1973a,b) for the Balearic Promontory region. The recovery of basalt during the cruise aboard the R/V Odón de Buen and from the flank of Emile Baudot Seamount, together with the olivine hyaloclastites dredged from the high (Zamarreño et al., 1985, 1989) support an igneous origin for the seamount.

\section{Petrology and chemistry of the basalt}

Rock sample EBR-8 from Emile Baudot Seamount was dredged at $38^{\circ} 43.630^{\prime} \mathrm{N}, 2^{\circ} 31.349^{\prime} \mathrm{E}$ at a water depth of $280 \mathrm{~m}$ (Fig. 2). Petrographic analyses of the rock sample indicate that the sample is a hypocrystalline porphyritic basalt with a vitreous matrix displaying some evidence of devitrification. Whereas the samples described by Zamarreño et al. $(1985,1989)$ have been altered to motukoreaite, phillipsite and calcite, sample EBR-8 does not display evidence of intense alteration or fracturing with only a few vesicles smaller than $0.5 \mathrm{~mm}$ filled with calcite. The sample major constituents are olivine, clinopyroxene, plagioclase and oxides of iron and titanium. The olivine is present as idiomorph and subidiomorph phenocrystals as large as $1.5 \mathrm{~mm}$. The borders of the olivine have been altered to serpentines, micas, talc and iron oxides and hydroxides. Its composition is rich in magnesium from $\mathrm{Fo}_{85}$ at the core to $\mathrm{Fo}_{82}-\mathrm{Fo}_{78}$ at the rim. The clinopyroxene appears to be fresh and vary in size from zoned and macled phenocryst, to $2 \mathrm{~mm}$ subidiomorphs and allotriomorphs and cryptocrystalline. The crystals display evidence of corrosion and reabsorption in its core. The composition of the clinopyroxene corresponds to diopside which in some instances is poorly zoned and in others display complex zoning. This composition is characteristic of alkaline lavas with high $\mathrm{Ca}+\mathrm{Na}$ content (Leterrier et al., 1982). Plagioclase is usually unaltered and appears in the form of microlite idiomorphs with a fluidal texture. Their composition corresponds to bytownites, near the limit of labradorite $\left(\mathrm{An}_{72}\right.$ to $\left.\mathrm{An}_{68}\right)$.

Major and trace element concentrations (Table 1) were determined by Actlabs (Canada) by X-ray fluorescence spectrometry and by inductively coupled plasma-mass spectrometry (ICP-MS). The analysed sample was treated with deionised water to remove seawater.

When the chemical composition of EBR-8 (Table 1) is plotted in a Total Alkali-Silica (TAS) diagram (Le Maitre et al., 1989), it falls within the basalt field.

Table 1

Chemical composition of basalt sample EBR-8

\begin{tabular}{lllllllllllll}
\hline $\mathrm{SiO}_{2}$ & $\mathrm{TiO}_{2}$ & $\mathrm{Al}_{2} \mathrm{O}_{3}$ & $\mathrm{Fe}_{2} \mathrm{O}_{3}$ & $\mathrm{FeO}$ & $\mathrm{MnO}$ & $\mathrm{MgO}$ & $\mathrm{CaO}$ & $\mathrm{Na}_{2} \mathrm{O}$ & $\mathrm{K}_{2} \mathrm{O}$ & $\mathrm{P}_{2} \mathrm{O}_{5}$ & $\mathrm{LOI}$ & $\mathrm{Total}$ \\
\hline 44.36 & 2.69 & 15.35 & 10.97 & 0.00 & 0.14 & 9.35 & 9.31 & 3.07 & 1.57 & 0.58 & 2.75 & 100.13 \\
$\mathrm{Ba}$ & $\mathrm{Rb}$ & $\mathrm{Sr}$ & $\mathrm{Y}$ & $\mathrm{Zr}$ & $\mathrm{Nb}$ & $\mathrm{V}$ & $\mathrm{Cr}$ & $\mathrm{Ni}$ & $\mathrm{Co}$ & $\mathrm{Hf}$ & $\mathrm{U}$ & $\mathrm{Th}$ \\
715 & 31 & 660 & 22 & 155 & 45 & 207 & 209 & 172 & 40 & 3.4 & 0.8 & 4.2 \\
$\mathrm{La}$ & $\mathrm{Ce}$ & $\mathrm{Pr}$ & $\mathrm{Nd}$ & $\mathrm{Sm}$ & $\mathrm{Eu}$ & $\mathrm{Gd}$ & $\mathrm{Tb}$ & $\mathrm{Dy}$ & $\mathrm{Er}$ & $\mathrm{Tm}$ & $\mathrm{Yb}$ & $\mathrm{Lu}$ \\
33.3 & 61.6 & 0.75 & 28.2 & 5.6 & 1.89 & 5.1 & 0.8 & 4.1 & 1.8 & 0.24 & 1.6 & 0.21 \\
\hline
\end{tabular}

$\mathrm{SiO}_{2}$ to LOI content in \%wt, $\mathrm{Ba}$ to $\mathrm{Lu}$ content in $\mathrm{ppm}$. 
Its alkalic content and normative composition (normative olivine and nepheline) corresponds to an alkaline rock. It is a basalt that has undergone some moderate process of differentiation with its $\mathrm{Mg} \#$ and $\mathrm{Ni}$ and $\mathrm{Cr}$ content being lower than those of primitive magmas. Although the rock does not display evidence of intense alteration, its marine location could have resulted in the partial alteration of its composition. Its $\mathrm{Ti}, \mathrm{Zr}, \mathrm{Y}$ and $\mathrm{Nb}$ content which are thought to be relatively immobile in aqueous fluids, confirmed its alkaline basalt character. One can come to a similar conclusion from its high $\mathrm{Ti} / \mathrm{V}$ ratio (between 50 and $100)$ and its low $\mathrm{TiO}_{2} / \mathrm{P}_{2} \mathrm{O}_{5}$ ratio which are typical of alkaline basalts (Winchester and Floyd, 1976; Shervais, 1982). Its immobile elements also permit us to characterize the tectonic setting of the basalt. Its high $\mathrm{Ti} / \mathrm{Y}(\gg 500)$ and $\mathrm{Zr} / \mathrm{Y}(>5)$ ratios are characteristic of interplate basalts and its high $\mathrm{Nb} / \mathrm{Y}(>2)$ ratio is typical of within-plate alkaline basalts (Fig. 4; Pearce, 1982; Meschede, 1986).

None of the above criteria, however, permits us to differentiate between continental and oceanic alkaline basalts. Using a $\mathrm{Y}-\mathrm{La}-\mathrm{Nb}$ diagram from Cabanis and Lecolle (1989), the analysed rock sample does not plot in the field of continental basalts, but in the field of intercontinental rift alkaline basalts. Such a plot, however, should be treated with caution due to the mobility of La and the absence of alkaline oceanic basalts in their diagram. The composition of EBR-
8 normalized to a "primordial mantle" (Thompson, 1982) reflects the enrichment in the more incompatible elements, similar to these displayed OIB, such as samples from the Canary Islands (Fig. 5), or the Neogene alkaline volcanic rocks east of the Iberian peninsula (Fig. 5), although less enriched in the incompatible elements ( $\mathrm{La}$ to $\mathrm{Lu}$ ). The spider-diagram is very similar to the basalt from the Catalan province with significant troughs at the $\mathrm{Rb}$ and $\mathrm{U}-\mathrm{Th}$ and the $\mathrm{Ba}$ and $\mathrm{Nb}$ peaks. The absence of a $\mathrm{K}$ trough in the Emile Baudot Seamount sample that is present in the other rocks could reflect a possible continental crustal contamination.

Comparison with samples from the Canary Islands shows, however, that the basalt from Emile Baudot Seamount is enriched in $\mathrm{Ba}, \mathrm{Rb}$ and $\mathrm{K}$, an enrichment that reflects the possible contamination from a continental crust. Such contamination is not unreasonable as Paleozoic rocks are exposed in Majorca and Minorca (Acosta et al., 2001a), and depth to the Moho discontinuity in Majorca is about $25 \mathrm{~km}$ (Dañobeitia et al., 1992), a depth value approaching that typical of continental crust.

\section{Age of EBR-8 sample}

The material used was represented by "whole rock" sample of 1 or $2 \mathrm{~g}$ with particle size varying

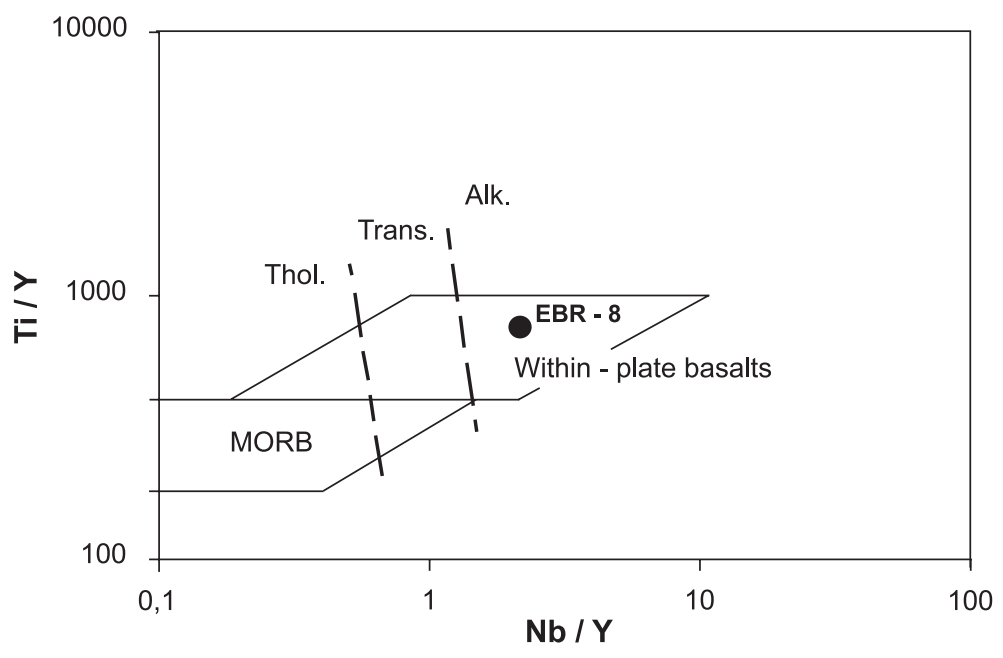

Fig. 4. Ti/ $\mathrm{Y}-\mathrm{Nb} / \mathrm{Y}$ discrimination diagram for basalts. From Pearce (1982). 


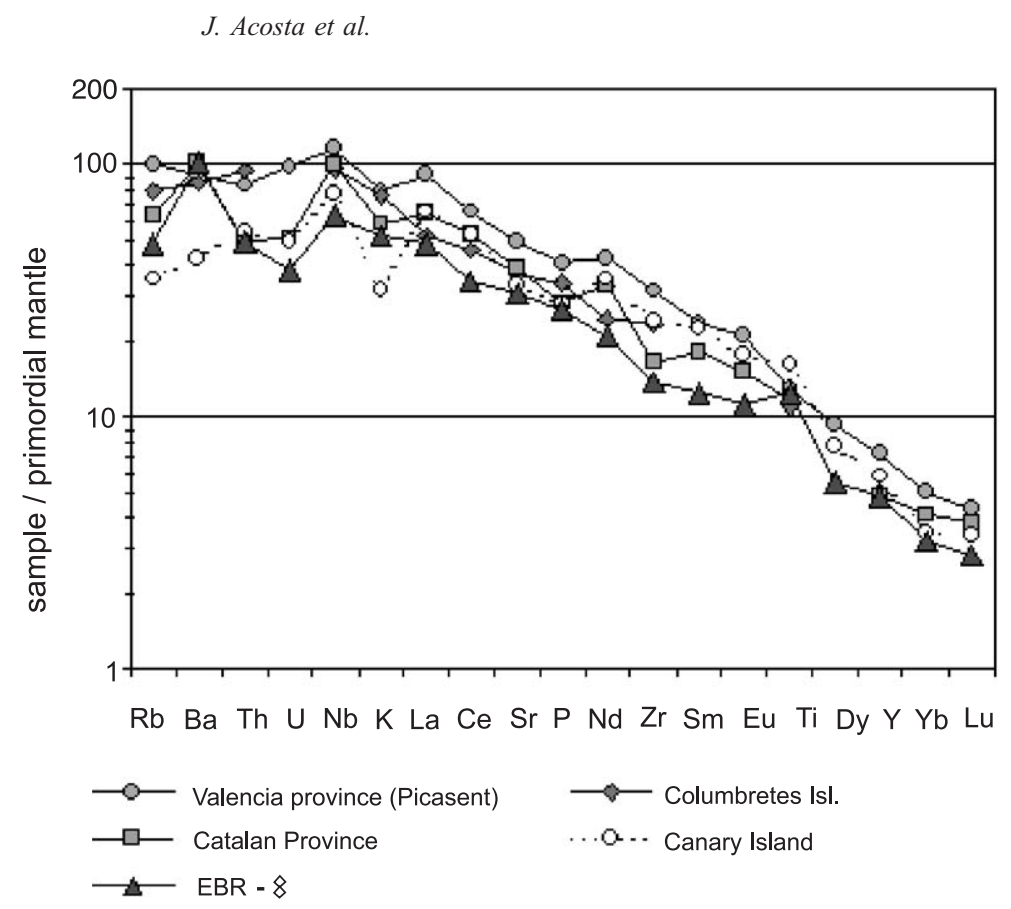

Fig. 5. Incompatible element abundances of EBR-8, Canary island average, Columbretes basalt (Aparicio and García, 1995), Valencia basalt (Ancochea and Huertas, 2003) and Catalan basalt (Cebriá et al., 2000), normalized to the composition of the primordial mantle (Thompson, 1982).

from 0.3 to $1 \mathrm{~mm}$. Argon was extracted by fusion after degassing at moderate temperature in high vacuum and ${ }^{38} \mathrm{Ar}$ tracer is added to the analysis using a continuous pipetting system. The potassium content was analysed by atomic absorption spectrometry.

Sample EBR-8 from Emile Baudot Seamount has been dated by the K/Ar method by Teledyne Isotopes Laboratory (Table 2). The age obtained, $1.46+0.18$ $\mathrm{Ma}$, is considered to be reliable. The percentage of ${ }^{40} \mathrm{Ar}^{*}$, of the order of $15 \%$, obtained during the

Table 2

$\mathrm{K}-\mathrm{Ar}$ radiometric age

\begin{tabular}{llllll}
\hline Sample & Coordinates & $\begin{array}{l}{ }^{40} \mathrm{Ar} * \\
\left(\mathrm{scc} / \mathrm{gr} \times 10^{-5}\right)\end{array}$ & $\begin{array}{l}\% \\
{ }^{40} \mathrm{Ar} *\end{array}$ & $\begin{array}{l}\% \mathrm{~K} \\
\text { Age } \\
(\mathrm{Ma})\end{array}$ \\
\hline EBR-8 & $\mathrm{N} \mathrm{38} 43.638$ & 0.0061 & 14.4 & 1.19 & $1.46 \pm 0.18$ \\
& $\mathrm{E} \mathrm{2} 2^{\circ} 31.349$ & 0.0075 & 16.1 & 1.20 & \\
\hline
\end{tabular}

Determination made by Teledyne Isotopes Lab., USA. The analytical errors were calculated according to Dalrymple and Lamphere (1969) method. The converted ages were calculated using the following constants: ${ }^{40} \mathrm{~K} / \mathrm{K}=1.167 \times 10^{-2}$ atoms \%; $\lambda \varepsilon=0.581 \times 10^{-10}$ year $^{-1}, \lambda \beta=4.962 \times 10^{-10}$ year $^{-1} ;{ }^{40} \mathrm{Ar}{ }^{36} \mathrm{Ar}$ atmosphere $=295.5$. analysis, is quite high for such a young rock with such a low $\mathrm{K}$ content.

\section{Discussion}

At least two models have been proposed for the origin of the western Mediterranean morphology. In one model, the Valencia Trough is inferred to be an early Miocene aborted rift formed behind a subduction zone and associated island arc. Collier et al. (1994), for example, proposed that the Balearic Promontory was formed by folding and thrust faulting at the same time that the Valencia Trough was created by extension. Others, such as Carminati et al. (1998), suggested that extension in the Valencia Trough was due to roll-back to the southeast of the northwest subducting African plate. Similarly, Gueguen et al. (1998) speculated that the opening of the back-arc Provençal-Valencia-Alboran basins was due to rollback of the African plate.

In the second model, the morphology of the western Mediterranean have been inferred to be the 
result of horizontal translation of microplates. In this, the morphology of the western Mediterranean Sea is the result of three tectonic events. Collision of Iberia and Adria against southern Eurasia during the first phase in Late Cretaceous-early Oligocene resulted in the formation of an accretionary wedge along eastern Spain (Vegas, 1992). In the second cycle, in late Oligocene-middle Miocene, rotated $30^{\circ}$ in a counter-clockwise direction creating the Gulf of Lions and the North Balearic Provençal Basin. At the same time, the Balearic Promontory moved away from the Spanish margin along transfer faults with the Valencia Trough opening behind it. Migration of the Balearic Promontory and rotation of the blocks making up the high is due to the westward migration of the Alboran plate to its present position east of the Strait of Gibraltar. As the Alboran plate moved westward, the South Balearic-Algerian Basin opened behind it (Vegas, 1992).

Volcanism in the region of the Balearic Promontory displays two cycles (Maillard et al., 1992; Martí et al., 1992). An early to middle Miocene calc-alkaline volcanism is associated with the compressive cycle, whereas the middle Miocene to Holocene alkaline volcanism is associated with extensional tectonics. Martí et al. (1992) differentiated three zones within the middle Miocene to Holocene volcanic province, the Catalan, Valencian and Columbretes provinces with each province located at different parts of the rift structure. Volcanic activity within the Catalan province ranges from $10 \mathrm{Ma}$ to Holocene, that of Columbretes from 1.0 to $0.3 \mathrm{Ma}$ (Aparicio et al., 1991) and in the Valencia Trough from 8.0 to 1.0 Ma (Ancochea and Huertas, 2003). Acosta et al. (2001a) have mapped a proposed fourth volcanic province, the Southwest Majorca Volcanic Field. Included within this field are 118 pinnacles that range in relief from 8 to more than $300 \mathrm{~m}$ and the $18-\mathrm{km}$ long and 3-km-wide Emile Baudot Seamount. Acosta et al. (2001a) speculated that the Southwest Majorca Field was the result of decompression associated with the extensional collapse of the low between Ibiza and Majorca in the Pliocene-Quaternary. However, they had no data to support such a hypothesis.

A K/Ar date $(1.46+0.18 \mathrm{Ma})$ from a basalt sample recovered from the flank of the Emile Baudot Seamount since their publication appears to support Acosta's et al. (2001a) contention that the Southwest
Majorca Field and Emile Baudot Seamount are the creations of early Pleistocene volcanicity. The excess Ar content of the sample recovered from the seamount indicates that this is a maximum age and that the volcanism probably took much later. Like the other intraplate, middle Miocene to Holocene fields in the region, volcanism in the Southwest Majorca Field is probably due to extension driven decompression. Limited sampling of this seamount does not preclude the possibility that the high is not solely a volcanic edifice, but represents an intruded uplifted continental block. If so then Emile Baudot seamount is comparable to the other highs in the region, Mont dels Oliva and Mont Ausias Marc east of Ibiza and Formentera. If the northeast-trending Emile Baudot is an intruded continental block then its geology is probably comparable to the lithology of the northeast trending Serres de Llevant along the southeast side of Majorca.

\section{Conclusion}

Subsidence of the South Balearic-Algerian Basin south of the Balearic Promontory in the western Mediterranean led to the collapse of the promontory between Eivissa (Ibiza) and Majorca. Decompression driven by this collapse in turn led to partial melting and subsequent volcanism that led to the construction of the 118 pinnacles in the 12-34-km-wide and 39km-long Southwest Majorca Volcanic Field and the Emile Baudot Seamount. Possibly, the seamount is not wholly igneous, but represents an intruded uplifted continental block. If so then Emile Baudot seamount is comparable to Mont dels Oliva and Mont Ausias Marc, two uplifted carbonate blocks east of Eivissa (Ibiza) and Formentera.

\section{Acknowledgements}

We express our appreciation to the Captain and crew of IEO's R/V Odón de Buen for their cooperation during the MOMBA cruise to the Balearic Promontory. Ken Sims of Woods Hole Oceanographic Institution was most helpful in checking our translation from Spanish to English of the report on the rock sample. A. Muñoz processed and drafted the multibeam figures. Thanks are also extended to D.J.W. 
Piper and two anonymous referees that greatly improved the manuscript. J. Martin-Dávila gave us his comments about the geomagnetism of Emile Baudot Seamount. This is a contribution of Spain's EEZ program.

\section{References}

Acosta, J., Serra, J., Herranz, P., Canals, M., Mateu, G., Guillen, J., Sanz, J.L., Calafat, A., San Gil, C., Catafau, H., Fornós, A., 1986. Resultados preliminares de geologia marina "Geocarbal-85/I", realizada en la plataforma continental de las Islas BalearesInformes Técnicos del Instituto Español de Oceanografia, vol. 44. Ministerio de Agricultura Pesca y Alimentacion, Madrid, Spain, $11 \mathrm{pp}$

Acosta, J., Herranz, P., Rey, J., Sanz, J.L., 1989. Resultados preliminares de la campaña de geología marina Carbal-88. Informes Técnicos del Instituto Español de Oceanografia, vol. 75. Madrid, Spain, $94 \mathrm{pp}$.

Acosta, J., Muñoz, A., Herranz, P., Palomo, C., Ballesteros, M., Vaquero, M., Uchupi, E., 2001a. Geodynamics of the Emile Baudot Escarpment the Balearic Promontory, Western Mediterranean. Mar. Pet. Geol. 128, 349-369.

Acosta, J., Muñoz, A., Herranz, P., Palomo, C., Ballesteros, M., Vaquero, M., Uchupi, E., 2001b. Pockmarks in the Eivissa Channel the western end of the Balearic Promontory (western Mediterranean) revealed by multibeam mapping. Geo Mar. Lett. $21,123-130$.

Acosta, J., Canals, M., López-Martinez, J., Muñoz, A., Herranz, P., Urgeles, R., Palomo, C., Casamor, J.L., 2002. The Balearic Promontory geomorphology (western Mediterranean): morphostructure and active processes. Geomorphology 49, 177-204.

Alla, G., Dessolin, D., Leenhardt, O., Pierrot, S., 1972. Donnés du sondage sismique continu concernant la sedimentation PlioQuaternarie en Méditerranée nod-occidentale. In: Stanley, D.J. (Ed.), The Mediterranean Sea: a Natural Sedimentation Laboratory. Dowden, Hutchinson \& Ross, Stroudsburg, PA, pp. 471-487.

Alonso, B., Canals, M., Got, H., Maldonado, A., 1991. Seavalleys related depositional systems in the Catalan Sea (northwestern Mediterranean Sea). AAPG Bull. 75, 1195-1214.

Ancochea, E., Huertas, M.J., 2003. Nuevos datos geocronológicos y geoquímicos de las manifestaciones volcánicas de Picasent y Cofrentes (Valencia). Geogaceta 32, 31-35.

Aparicio, A., García, R., 1995. El volcanismo de las islas Columbretes (Mediterráneo occidental). Quimismo y mineralogía. Bol. Geol. Min. 106-5, 468-488.

Aparicio, A., Mitjavila, J.M., Araña, V., Villa, J., 1991. La edad del volcanismo de las Islas Columbrete Gr e y Alborán (Mediterráneo Occidental). Bol. Geol. Min. 102-4, 562-570.

Auzende, J.M., Bonnin, J., Olivet, J.L., 1973a. The origin of the western Mediterranean Basin. J. Geol. Soc. (London) 129, $607-620$.
Auzende, J.M., Olivet, J.-L., Pautot, G., 1973b. Balearic Islands southern prolongation. In: Ryan, W.B.F., Hsü, J.K., et al., (Eds.), Initial Reports of the Deep Sea drilling Project XIII. U.S. Govt. Printing Office, Washington DC, pp. 1441-1447.

Cabanis, B., Lecolle, M., 1989. Le diagramme La/10-Y/15-Nb/8: un outil pour la discrimination des series volcaniques et la mise en evidence des processus de melange et/ou de contamination crustale. C. R. Acad. Sci. Paris Ser. II 309, 2023-2029.

Carminati, E., Wortel, M.J.R., Spakman, W., Sabadini, R., 1998. The role of slab detachment processes in the opening of the western-central Mediterranean basins: some geological geophysical evidence. Earth Planet. Sci. Lett. 160, 651-665.

Cebriá, J.M., López-Ruiz, J., Doblas, M., Oyarzun, R., Hertogen, J., Benito, R., 2000. Geochemistry of the Quaternary alkali basalts of Garrotxa (NE Volcanic Province, Spain): a case of double enrichment of the mantle lithosphere. J. Volcanol. Geotherm. Res. 102, 217-235.

Collier, J.S., Buhl, P., Torné, M., Watts, A.B., 1994. Moho lower crustal reflectivity beneath a young rift basin: results from a two-ship, wide aperture seismic-reflection experiment in the Valencia Trough (western Mediterranean). Geophys. J. Int. $118,159-180$.

Dalrymple, G.B., Lamphere, M.A., 1969. Potassium-Argon dating; principles, techniques applications to geochronology W.H. Freeman, San Francisco. 258 pp.

Dañobeitia, J.J., Arguedas, M., Gallart, J., Banda, E., Makris, J., 1992. Deep crustal configuration of the Valencia trough its Iberian Balearic borders from extensive refraction wide-angle reflection seismic profiling. Tectonophysics 203, 37-55.

Desforges, G., 1973. Contribution a la connaissance de la Mediterranée occidentale. Etude sédimentologique de roches prélevées par dragage et application à la diagenèse précoce en eau profonde. Thése 3é cycle, Paris. 311 pp.

Escutia, C., Maldonado, A., 1992. Paleogeographic implications of the Messinian surface in the Valencia Trough, northwestern Mediterranean Sea. Tectonophysics 203, 353-367.

Grupo de Trabajo ZEE, 2001. Mapa Batimétrico del Mar Balear y Golfo de Valencia, Mediterrráneo occidental (1:500.000). Zona Económica Exclusiva Española. Edita; Instituto Español de Oceanografia (with abstract in Spanish and English).

Gueguen, E., Doglioni, C., Fernández, M., 1998. On the post-25 Ma geodynamic evolution of the western Mediterranean. Tectonophysics 298, 259-269.

International Hydrographic Organization, 1997. Standards for Hydrographic Surveys, 4th edition. Special Publication, vol. 44.

Le Maitre, R.W., Bateman, P., Dudek, A., Keller, J., Lameyre, J., Le Bas, M.J., Sabine, P.A., Schmid, R., Sorensen, H., Streckeisen, A., Woolley, A.R., Zanettin, B., 1989. A Classification of Igneous Rocks Glossary of Terms Blackwell, Oxford. 148 pp.

Leterrier, J., Maury, R.C., Thonon, P., Girard, D., Marchal, M., 1982. Clinopyroxene composition as a method of identification of the magmatic affinities of palaeo-volcanic series. Earth Planet. Sci. Lett. 59, 139-154.

Maillard, A., Mauffret, A., Watts, A.B., Torné, M., Pascal, G., Buhl, P., Pinet, B., 1992. Tertiary sedimentary history of the Valencia trough (western Mediterranean). Tectonophysics 203, $57-75$. 
Martí, J., Mitjavila, J., Roca, E., Aparicio, A., 1992. Cenozoic magmatism of the Valencia trough (western Mediterranean): relationship between structural evolution volcanism. Tectonophysics 203, 145-165.

Meschede, M., 1986. A method of discriminating between different types of mid-ocean ridge basalts continental tholeiites with the $\mathrm{Nb}-\mathrm{Zr}-\mathrm{Y}$ diagram. Chem. Geol. 56, 207-218.

Muñoz, A., Acosta, J., Palomo, C., Herranz, P., Sanz, J.L., Molinero, J., Gómez, R., 1989. Datos batimétricos y sísmicos en el ámbito de la investigación de la Zona Exclusiva Española. $\mathrm{I}^{\mathrm{a}}$ Asamblea Hispano-Portuguesa de Geodesia y Geofísica, Almería, Spain. 6 pp.

Palomo, C., de Miguel, J., Acosta, J., Sanz, J.L., Aranaz, F., 1974. Estudio geomagnético de tres submarinos en el Mar Balear. I ${ }^{\mathrm{a}}$ Asamblea Nacional de Geodesia y Geofísica, Madrid. Comunicaciones, vol. II, pp. 895-923.

Palomo, C., Acosta, J., de Andrés, J., Herranz, P., Rey, J., Sanz, J.L., 1976. Perfiles geofísicos entre la península y las Islas Baleares. II ${ }^{\mathrm{a}}$ Asamblea Nacional de Geodesia y Geofísica, Madrid. Comunicaciones, vol. III, pp. 1617-1627.

Pearce, J.A., 1982. Trace element characteristics of lavas from destructive plate boundaries. In: Thorpe, R.S. (Ed.), Andesites:
Orogenic Andesites and Related Rocks. Wiley, Chichester, pp. 525-548.

Sabat, F., Roca, E., Muñoz, J.A., Vergés, J., Santanach, P., Sans, M., Masana, E., Estévez, A., Santistan, C., 1995. Role of extension compression in the evolution of the eastern margin of Iberia: the ESCI-Valencia Trough seismic profile. Rev. Soc. Geol. Esp. 8, $431-448$.

Shervais, J.W., 1982. Ti-V plots the petrogenesis of modern ophiolitic lavas. Earth Planet. Sci. Lett. 59, 101-118.

Thompson, R.N., 1982. British Tertiary volcanic province. Scott. J. Geol. 18, 49-107.

Vegas, R., 1992. The Valencia trough the origin of the western Mediterranean basins. Tectonophysics 203, 249-261.

Winchester, J.A., Floyd, P.A., 1976. Geochemical magma type discrimination; application to altered metamorphosed basic igneous rocks. Earth Planet. Sci. Lett. 28, 459-469.

Zamarreño, I., Plana, F., y Vázquez, A., 1985. Motukoreaita, filipsita y calcite: una secuencia de alteración submarina de basaltos en el margen sur-Balear. Acta Geol. Hisp. 20, 81-93.

Zamarreño, I., Plana, F., Vázquez, A., 1989. Motukoreaite: a common alteration product in submarine basalts. Am. Mineral. 74, 1054-1058. 